\title{
FT-Raman spectroscopic study of skin wound healing in diabetic rats treated with Cenostigma macrophyllum Tul
}

\author{
Nayana Pinheiro Machado de Freitas Coelho*, Leandro Raniero, Charlytton Luís Sena da Costa, Antônio \\ Luís Martins Maia Filho, Marcelino Martins, Airton Abrahão Martin, Emília Ângela Loschiavo Arisawa
}

\begin{abstract}
Introduction: Patients with diabetes mellitus exhibit a delay in the lesion repair process. The active components of Cenostigma macrophyllum may represent a viable alternative to facilitate the recovery of these lesions. The aim of this study was to evaluate the effects of emulsion oil-water Cenostigma macrophyllum in the repair process of lesions in rats with induced diabetes. Methods: 63 male rats (Wistar, 200-250 g body weight, 30-40 days old) were distributed into the following groups: control (C), diabetic (D) and diabetic treated with Cenostigma macrophyllum (P), subdivided based on the experimental times, days 7, 14 and 28, with 21 animals per main group. Diabetes mellitus (DM) was induced by administration of streptozotocin $(50 \mathrm{mg} / \mathrm{kg}$ via penile vein and 12-h fasting) and confirmed at day 21 (glycemic index $>240 \mathrm{mg} / \mathrm{dL}$ ). In the animals of group P, $0.5 \mathrm{ml}$ of the oil-water emulsion obtained from the plant seed was used. The samples were removed and hemisectioned, and one portion was used for the quantitative histological analysis of collagen using Masson's trichrome staining, while another portion was analyzed by FT-Raman spectroscopy. Results: A higher percentage area of the volume of collagen fibers was observed for the experimental time Day 14 in group $\mathrm{P}$ compared with group D $(\mathrm{p}<0.001)$. Regarding the ratio of areas of the amides I $\left(1700-1600 \mathrm{~cm}^{-1}\right)$ and III (1245-1345 $\left.\mathrm{cm}^{-1}\right)$, the groups D and P show the opposite behavior. Conclusion: Cenostigma macrophyllum accelerated the repair process in skin of diabetic ratsfor14 days.
\end{abstract}

Keywords Cenostigma macrophyllum, Raman spectroscopy, Tissue repair.

\section{Introduction}

Diabetes mellitus is a disorder characterized by deficient insulin production associated with metabolic changes that delay cell proliferation and reduce granulation tissue formation and collagen metabolism, consequently impairing tissue repair (Esteves et al., 2008; Galkowska et al., 2006). The number of people in the world with diabetes is increasing each year, particularly in the young population. This fact highlights the importance of the discovery of new drugs for the treatment of conditions associated with this disease such as skin wounds (Calcutt et al., 2009; Carvalho et al., 2010).

According to Albertini et al. (2007) and Piva et al. (2011), the process of skin wound healing involves a series of cellular events until the complete reorganization of collagen fibers is achieved. However, in diabetic patients skin wound healing is prolonged because of deficient angiogenesis and a reduction in the number of remodeling cells which compromise collagen matrix formation (Bernardi et al., 2012).

Recent studies have evaluated medicinal plants for the treatment of diabetic wounds in an attempt to accelerate the healing process (Papanas and Maltezos, 2011; Ponrasu and Suguna, 2012; Wang and Que,
2011). The results of these studies showed that the plants tested favored early wound closure as well as adequate organization of collagen fibers, the main molecules participating in this process (Zhang et al., 2011).

The medicinal plant Cenostigma macrophyllum Tul. var. Acuminata Teles Freire (Caesalpiniaceae) contains chemical compounds that act on the formation of collagen fibers and have anti-inflammatory activity. These compounds include flavonoids, tocopherols, sterols and $\beta$-carotene, which have been associated with the acceleration of diabetic wound healing (Silva et al., 2007). In addition, biflavones that exhibit healing and anti-inflammatory activity have been isolated from the leaf extracts of Cenostigma macrophyllum Tul. (Silva et al., 2007; Sousa et al., 2007). However, there are no studies investigating the effect of this plant on the healing of diabetic skin wounds in rats.

Raman spectroscopy is a noninvasive, real-time method that permits rapid characterization of tissue by detecting subtle changes in the molecular vibrational modes of samples. Studies using this technique are performed to identify the tissue and differentiate 
between normal and pathological spectra, according to the structure and chemical composition of the tissue (Kozielski et al., 2011). The spectra are classified according to the main biochemical components of the tissue using statistical methods such as principal component analysis and linear discriminant analysis (Ebaid et al., 2011; Kozielski et al., 2011; Lieber et al., 2008).

Within this context, the objective of the present study was to evaluate the efficacy of tissue repair in diabetic wounds treated with an oil-water emulsion of Cenostigma macrophyllum Tul.

\section{Methods}

The present study was conducted in accordance with Animal Testing Law No. 11,794/2008, at the Laboratory of Physiology, Differential Integral School (FACID), Teresina, Piauí State, Brazil. The study was approved by the Research Ethics Committee of FACID (Permit No. 263/2009). Sixty-three adult male Wistar rats (Rattus norvegicus), aged 30-40 days and weighing 200-250 g, were used. The animals were maintained at the animal house of the Institute of Higher Education in individual cages under a 12-h light-dark cycle, with food and water available ad libitum.

\section{Experimental groups}

The rats were randomly divided into three groups of 21 animals each before the induction of diabetes mellitus and identified according to treatment: control (C), diabetic (D), and diabetic treated with an oilwater emulsion of Cenostigma macrophyllum Tul. (P). Each group was divided into three subgroups of 7 animals each according to experimental time: 7 (A), 14 (B) and 28 (C) days. Diabetes was induced in animals of groups D and P (Ebaid et al., 2011) and was confirmed by blood glucose measurement with an Accu-Chek ${ }^{\circledR}$ glucose meter on day 21 after induction. Diabetes was defined as a blood glucose level $>240 \mathrm{mg} / \mathrm{dl}$. Only animals of group P (PA, PB and $\mathrm{PC}$ ) received an application of $0.5 \mathrm{ml}$ of the oilwater emulsion of Cenostigma macrophyllum. These animals were treated from the day of confirmation of diabetes for different periods of time (7, 14 and 28 days). Animals of groups $\mathrm{C}$ and $\mathrm{D}$ did not receive any treatment.

\section{Tissue injuries}

All animals were anesthetized by intramuscular injection of $10 \%$ ketamine hydrochloride $(0.1 \mathrm{ml} / 100 \mathrm{~g} / \mathrm{kg})$ and $2 \%$ xylazine hydrochloride at the same dose (Martins et al., 2006). Next, an area measuring $6 \times 4 \mathrm{~cm}$ was shaved in the dorsolateral region of the animal and cleaned with $4 \%$ iodinated alcohol. A circular injury measuring $2.5 \mathrm{~cm}$ in diameter was then created in the center of this area with a metallic instrument equipped with a No. 4 blade until complete removal of the tissue. After surgery, the animals received prophylaxis consisting of deep intramuscular injection of a single dose $(0.02 \mathrm{ml} / 100 \mathrm{~g}$ body weight $)$ of broad-spectrum Pentabiótico (Fort Dodge ${ }^{\circledR}$ ). All procedures were performed in a quiet room with minimal manipulation to avoid stress to the animal.

\section{Preparation of the oil-water emulsion of Cenostigma macrophyllum}

The Cenostigma macrophyllum seeds collected were dried, hulled, ground, and subjected to hexane extraction at room temperature in the dark for $30 \mathrm{~min}$ under periodic stirring. The oil was obtained by filtering the hexane extract and concentration in a rotary evaporator at $45^{\circ} \mathrm{C}$ under reduced pressure. The oil was stored in an amber bottle until use. Next, the procedures for preparation of the emulsion were performed, which need to be kept confidential since they are in the process of being patented.

\section{Quantitative analysis of fibrillar collagen}

For quantitative analysis of the volume occupied by collagen fibers in the newly formed tissue, skin fragments were removed from the animals, mounted on slides and stained with Masson's trichrome, which stains collagen fibers blue (Figure 1A). Images of the slide were acquired with a Nikon Eclipse E600 ${ }^{\circledR}$ microscope (400X magnification) coupled to a Nikon DXM1200F ${ }^{\circledR}$ digital video camera. High-resolution digital images were captured by the Nikon software (ACT-1 version $2.622000^{\circledR}$ ) of a microcomputer coupled to the system. The images were transformed into monochromatic images, which changed blue into white areas and the other areas into black areas (Figure 1B).

The Image J program was used to calculate the following parameters: 1) reference area indicated by the dotted lines in Figure 1A $\left(A_{R}\right)$, and 2) area of collagen fibers, i.e., the white area $\left(\mathrm{A}_{\mathrm{CF}}\right)$. The area fraction occupied by a structure in a two-dimensional space corresponds to its volume fraction in a threedimensional space of the tissue where it is present. Thus, the percent volume of collagen fibers in the wound can be calculated using the following equation (Gundersen et al., 1988):

$V_{C}(\%)=\frac{A_{L} \cdot T \cdot A_{C F}}{A_{R}} \cdot 100$ 

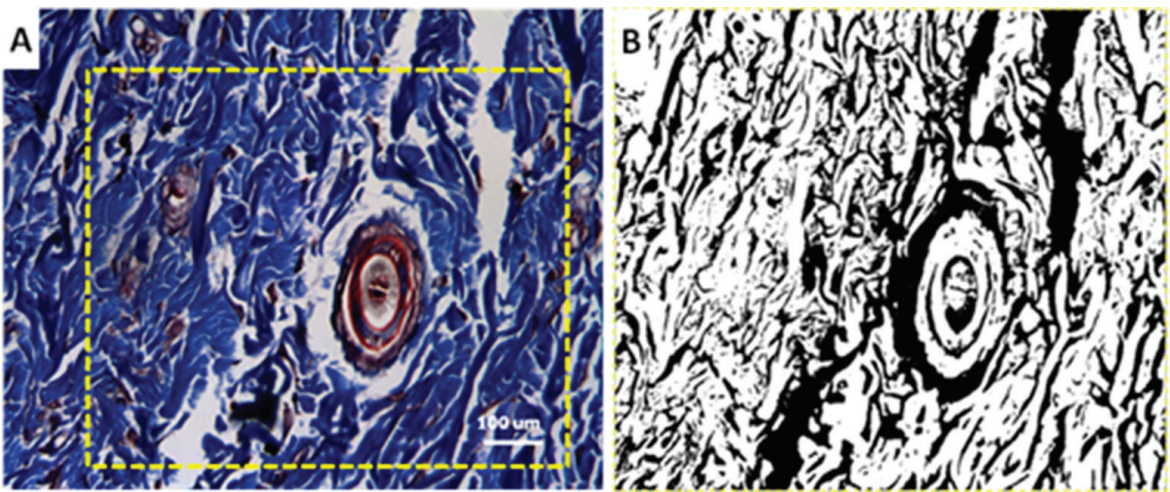

Figure 1. Photomicrographs of collagen fibers in the papillary dermis distributed throughout the tissue (A). Segmented image with the selection of collagen (B). Masson Trichomics (400X).

Where $A_{\mathrm{L}}$ is the final wound area (measured in the animal) and $T$ is the wound thickness. The surgical wounds were created in a standard manner, i.e., at the same anatomical location on the animal's back and comprising the same area and depth for all animals. The maximum depth of the wound, which corresponds to its thickness, was the reticular dermis. However, slides containing wound areas that exceeded this depth were excluded from the analysis.

Five to ten randomly selected digital images of each histological section, which covered the entire length of the newly formed tissue, were used for this analysis. The results of the quantitative analysis of collagen were analyzed statistically by ANOVA followed by the Tukey test, adopting a 95\% confidence interval and $\mathrm{p}<0.05$. Statistical analysis was performed using the GraphPad Prism 5.0 program.

\section{FT-Raman spectroscopy}

For this analysis, the animals were killed with an overdose of sodium pentobarbital $(60 \mathrm{mg} / \mathrm{kg})$ and tissue samples were removed, immediately labeled, transferred to cryogenic tubes (Nalgene ${ }^{\circledR}, 1.2 \mathrm{ml}$ ), and stored in liquid nitrogen $\left(-196{ }^{\circ} \mathrm{C}\right)$ to preserve the tissue structures until the time of Raman spectroscopy. The samples were individually thawed at room temperature and stored in $0.9 \%$ saline to preserve structural characteristics of the tissue. Next, the samples were placed in a aluminum sample holder $(1 \mathrm{~cm}$ in diameter) with a hole in the center $(1.5 \mathrm{~mm})$, covered with glass coverslips, and positioned in front of the exit of the laser beam. Spectra were collected through the objective lens.

The sample spectra were obtained with an RFS 100/S FT-Raman spectrometer (Bruker ${ }^{\circledR}$, Germany) equipped with a $\mathrm{Ge}$ detector and Nd:YAG laser (1,064 $\mathrm{nm}$ wavelength) as the excitation light source and coupled to a computer with the OPUS software (version 4.2). A total of 600 scans were collected in the spectral range of $1,800-400 \mathrm{~cm}^{-1}$ at a spectral resolution of $4 \mathrm{~cm}^{-1}$, laser power of $110 \mathrm{~mW}$, and acquisition time of $15 \mathrm{~min}$.

To subtract the effect of tissue fluorescence from the spectra, a baseline was generated with a Matlab routine using a fifth-order polynomial. An average spectrum was calculated for each sample by averaging three measurements at random points. All spectra were normalized by dividing the average spectrum by its largest value before statistical analysis. Principal component analysis was performed over the entire spectral range to reduce the size of the dataset. Five principal components ( $\mathrm{PC} 1, \mathrm{PC} 2, \mathrm{PC} 3, \mathrm{PC} 4$ and $\mathrm{PC} 5)$ were used for this analysis. The groups were separated by linear discriminant analysis and hierarchical cluster analysis using the Minitab ${ }^{\circledR}$ (14.20) software.

\section{Results}

Analysis of the percent volume fraction of collagen fibers in the wound area showed a significant difference between groups $\mathrm{D}$ and $\mathrm{P}$ after 7 days $(\mathrm{p}<0.05)$. At 14 days, significantly greater collagen deposition was observed in group $\mathrm{P}$ when compared to group $\mathrm{D}(\mathrm{p}<0.001)$ (Figure 2).

The PCs were calculated considering the variance of the Raman spectra in the spectral range from 1,800 to $400 \mathrm{~cm}^{-1}$. Figure 3 shows the results of the LDA using a cross-validation method and the 5 PCs as a function of the experimental time of the treatment (Days 7, 14 and 28). For Day 14, there is a greater difference between the groups, leading to a separation of $92.9 \%$. In this context, a more detailed spectral analysis was performed for this time point (Figure 3).

Figure 4 presents a dendrogram using groups C, D and $\mathrm{P}$ for the experimental time Day 14. Importantly, in this graph, groups $\mathrm{C}$ and $\mathrm{P}$ were mixed, indicating that the biochemical variations of both groups are 
similar. This similarity was also observed in the LDA, where 1 sample of group $\mathrm{C}$ was classified as group $\mathrm{P}$, lowering the discrimination value.

Figure 5 shows the plot of average spectra obtained for groups $\mathrm{C}, \mathrm{D}$ and $\mathrm{P}$ at 14 days. The black line

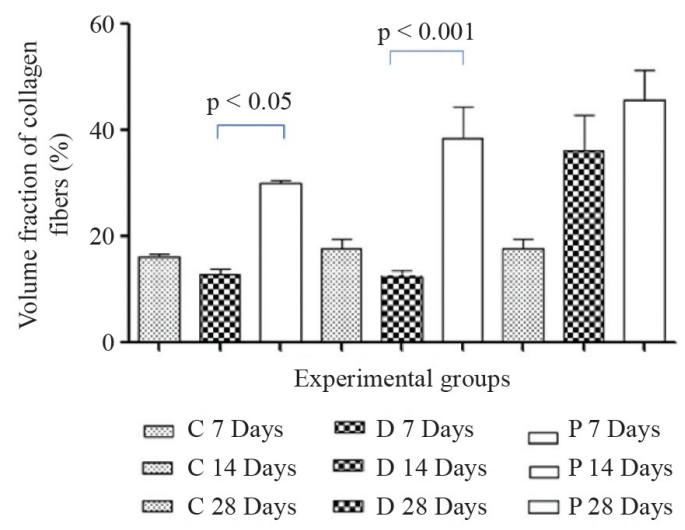

Figure 2. Fraction percentage volume of collagen fibers in the different experimental groups, depending on the experimental periods of 7, 14 and 28 days studied.

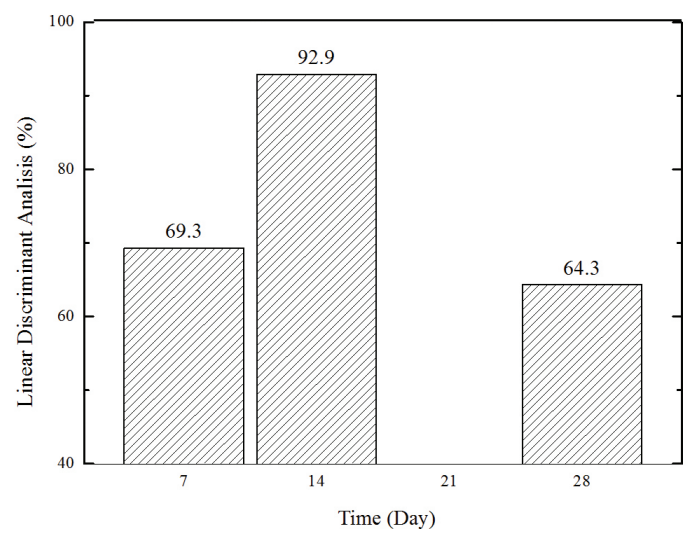

Figure 3. Linear Discriminant Analysis of Raman spectra using PC1-PC5 for classification, based on the experimental periods of 7,14 and 28 days studied.

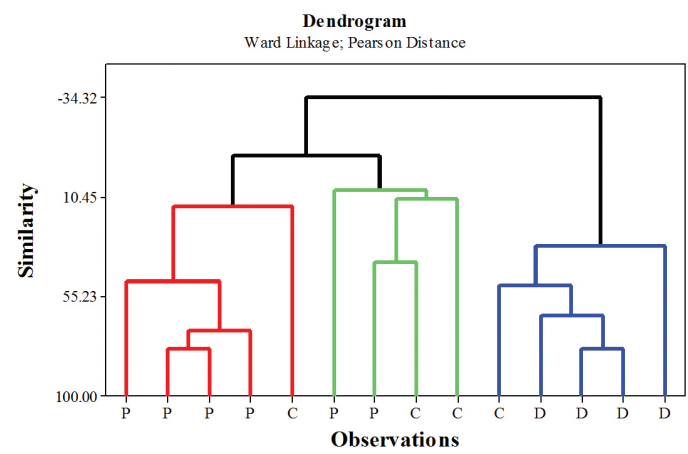

Figure 4. Dendrogram of the groups with the highest percentage of discrimination, the experimental time of 14 days. indicates the mean and the shaded light gray area the standard deviation. The Raman spectra obtained for group $\mathrm{C}$ are typical of normal skin, showing lower half-height width. The spectra obtained for groups $\mathrm{D}$ and $\mathrm{P}$ have lower standard deviations compared to control, a finding indicating the presence of chemical changes in diabetic tissue.

The area ratios of amide I (1700-1600 $\left.\mathrm{cm}^{-1}\right)$ to amide III $\left(1245-1345 \mathrm{~cm}^{-1}\right)$ regions are shown in Figure 6. As can be seen in the figure, groups $P$ and D show an opposite behavior, with group P reaching a peak at 14 days, whereas group $D$ presented a lower value than on day 7 . The ratios obtained for the control group remained practically constant throughout the period studied.

\section{Discussion}

Albertini et al. (2007), Carvalho et al. (2010) and Galkowska et al. (2006) reported significant results of different types of treatment for diabetic wound healing. A delay occurs in the proliferative phase in diabetic wounds, which results in inadequate collagen fiber formation due to tissue ischemia induced by chemical mediators of inflammation and inadequate neovascularization, contributing to deficient wound healing. In this respect, the quantitative analysis of

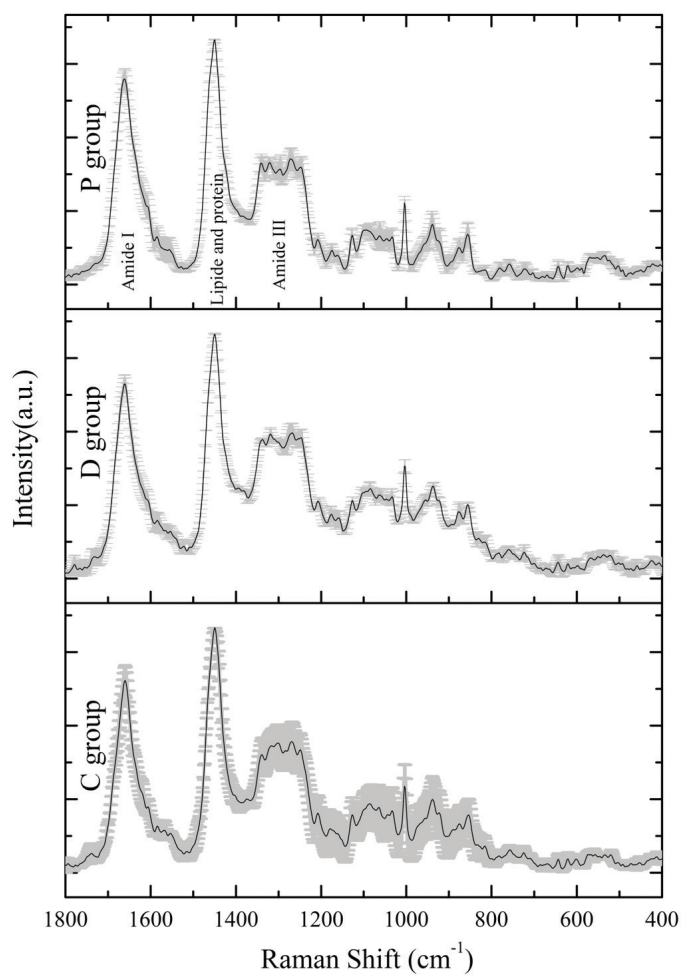

Figure 5. Raman spectra of the averages of the group sin the timetrial 14 days, with standard deviation in light gray. 


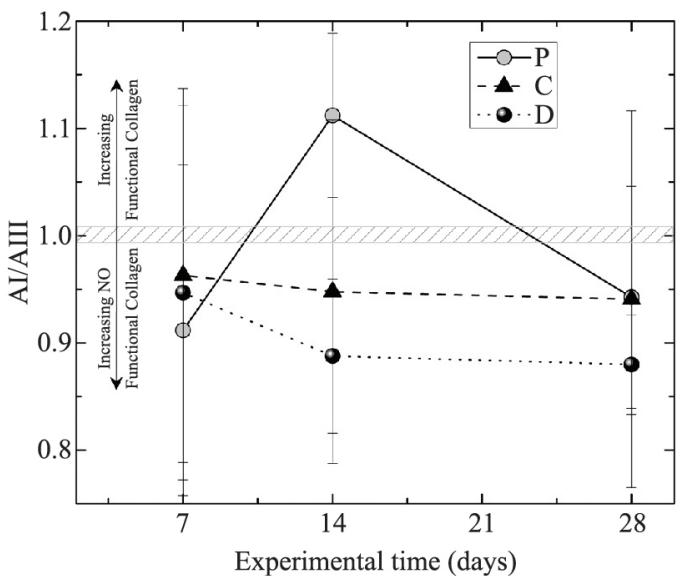

Figure 6. Ratio of areas Amide I /Amide III of the groups studied in different experimental times.

fibrillar collagen is important since calculation of the collagen volume fraction permits to infer on the progression of collagen fiber formation at different experimental times. Other studies also evaluated the phases of collagen formation during diabetic wound healing (Harinantenaina et al., 2006; Ponrasu and Suguna, 2012; Wang and Que, 2011).

In the present study, the effect of a delay in the proliferative phase during wound healing can be clearly seen in Figure 2, in which the percent volume fraction of collagen fibers was practically constant in groups D7 and D14, but increased exponentially in group D28 indicating the third phase of the healing process (remodeling phase) that is characterized by increased formation and organization of collagen fibers.

The linear increase of collagen volume observed in groups P7, P14 and P28 clearly demonstrates the beneficial effect of application of Cenostigma macrophyllum Tul. on the wound healing process. Whereas the onset of the proliferative phase usually occurs late in diabetic rats (after 14 days), application of the emulsion induced collagen formation as early as on day 7 (P7). As a consequence, the collagen volume fraction was approximately $15 \%$ higher in specimens of group P28 when compared to group C28.

New drugs for the treatment of skin wounds in patients with diabetes mellitus are designed to accelerate wound healing, which is crucial for these patients. Recent studies have shown that medicinal plants favor neovascularization and the formation of collagen fibers during tissue repair (HonórioFrança et al., 2008; Zhang et al., 2011). Cenostigma macrophyllum Tul. var. Acuminata Teles Freire is an arboreal species of the family Caesalpiniaceae which is found in different regions of Brazil. The plant contains chemical compounds such as phytosterols, which reduce the time of the inflammatory response, pro-vitamin A, vitamin $\mathrm{E}$ and fatty acids that act on collagen formation (Silva et al., 2007; Sousa et al., 2007). Therefore, the study of the effect of this plant on wound healing in diabetic rats is important since reports in the literature are sparse.

In Raman spectra, the main vibrational bands related to the wound healing process are those corresponding to the presence of collagen-forming protein (Kozielski et al., 2011; Lieber et al., 2008). Collagen spectral bands are found at the following positions: 1,730-1,740 collagen III; 1,654-1,655 amide $\mathrm{I}(\mathrm{C}=\mathrm{O}$ stretching mode of proteins, $\alpha$-helix conformation $) / \mathrm{C}=\mathrm{C}$ lipid stretch; $1,450-1,500$ stretching $\left(\mathrm{CH}_{2}\right)$-lipids, glycosaminoglycans, metalloproteinases, collagens and residues, and 1,245-1,345 amide IIIcollagen.

The results of linear discriminant analysis showed significant differences between groups and between the time points studied. The highest percentage of discrimination of the data was observed at 14 days. The dendrogram showed similar wound healing in diabetic rats treated with the plant emulsion and healthy control animals at this time point, grouping them in the same branch. These results agree with the literature since higher collagen fiber formation is observed in normal individuals during the proliferative phase at about 14 days after injury (Ebaid et al., 2011; Honório-França et al., 2008; Ponrasu and Suguna, 2012). Taken together, the results suggest that application of an oil-water emulsion of Cenostigma macrophyllum seeds accelerates the healing of diabetic wounds, increasing the percent volume fraction of collagen fibers.

Few studies have investigated the effect of Cenostigma macrophyllum Tul. on tissue repair. Coelho et al. (2013) evaluated wound healing in diabetic rats using the same plant and observed a reduction in the inflammatory process after 7 days, as demonstrated by the quantitative analysis of inflammatory cells and of nitric oxide, an important chemical mediator of inflammation. The authors also reported an increase in collagen fiber formation after 14 days.

Figure 6 shows a predominance of amide III, a structure related to the precursor molecule of collagen, procollagen, in its nonfunctional form, indicating an early stage of tissue repair (Zhang et al., 2011). On the other hand, a predominance of amide I would indicate the presence of functional collagen, especially collagens, I, III, IV, V, and VII which are associated with different tissue functions such as the formation of loose collagen fibers (superficial dermis), dense collagen fibers (deep dermis), and 
basement membrane which connects the epidermis to the dermis. This figure shows the ratio between amide I and amide III bands, with the band centered at 1 indicating equal amounts of procollagen and collagen. The arrows in the figure help understand the trend of points, i.e., ratios higher than 1 indicate a relative increase in functional collagen, whereas a ratio less than 1 indicates an increase in procollagen. Therefore, the study of the process of wound healing in diabetes involves the understanding of the structures and biochemical components of collagen, a protein that plays an important role in biological tissues (Kim et al., 2000; Oliveira et al., 2012).

A higher mean value of functional collagen was observed in the control group after 7 days when compared to specimens of the diabetic groups, indicating that wound healing tends to progress as observed in animals of the control group. However, a strong trend towards an increase in procollagen was observed in group D until 14 days, remaining practically constant until 28 days. These results suggest possible difficulties in the synthesis of functional collagen molecules. On the other hand, specimens of group P14 exhibited an increase in the amount of functional collagen, suggesting that the active ingredients of the plant are effective in wound healing, accelerating the synthesis of this molecule. Overall, the Cenostigma macrophyllum Tul. extract showed a significant influence on the healing of experimental wounds, increasing the deposition of collagen fibers, as demonstrated by histomorphometric analysis and by the area ratio of amide I to amide III regions in the Raman spectra. In addition, diabetic rats treated with this extract exhibited collagen formation at 14 days that was similar to that seen in healthy animals. This promising result demonstrates the local action of the extract and points to future use for topical wound treatment.

\section{Acknowledgments}

The authors thank the Piauí Research Foundation (FAPEPI) and Differential Integral School (FACID) for the scholarships granted. We also thank Mariana Helena Chaves for providing the material used in this study.

\section{References}

Albertini R, Villaverde AB, Aimbire F, Salgado MA, Bjordal JM, Alves LP, Munin E, Costa MS. Antiinflammatory effects of low-level laser therapy (LLLT) with two different red wave lengths $(660 \mathrm{~nm}$ and $684 \mathrm{~nm})$ in carrageenaninduced rat paw edema. Journal of Photochemistry and Photobiology B. 2007; 89:50-5. PMid:17920925. http:// dx.doi.org/10.1016/j.jphotobiol.2007.08.005
Bernardi S, Severini GS, Zauli G, Secchiero P. Cellbased therapies for diabetic complications. Experimental Diabetes Research. 2012; 2012:82504. http://dx.doi. org/10.1155/2012/872504

Carvalho PTC, Silva IS, Reis FA, Pereira DM, Aydos RD. Influence of ingaalp laser on the healing of skin wounds in diabetic rats. Acta Cirúrgica Brasileira. 2010; 25(1):719. http://dx.doi.org/10.1590/S0102-86502010000100016

Calcutt NA, Cooper ME, Kern TS, Schmidt AM. Therapies for hyperglycaemia-induced diabetic complications: from animal models to clinical trials. Nature Reviews Drug Discovery. 2009; 8(5):417-29. PMid:19404313. http:// dx.doi.org/10.1038/nrd2476

Coelho NPMF, Nogueira VC, Cardoso MAG, Lopes LS, Nascimento PP, Rocha ES, Silva CLP, Arisawa EAL. Cenostigma macrophyllum Tul. on the healing of skin wounds in rats with Diabetes mellitus. Acta Cirúrgica Brasileira. 2013; 28(8):594-600. http://dx.doi.org/10.1590/ S0102-86502013000800007

Ebaid H, Salem A, Sayed A, Metwalli A. Whey protein enhances normal inflammatory responses during cutaneous wound healing in diabetic rats. Lipids in Health and Disease. 2011; 10:235. PMid:22168406 PMCid:PMC3254143. http://dx.doi.org/10.1186/1476-511X-10-235

Esteves JC, Aranega AM, Borrasca AG, Fattah CMRS, Garcia-Júnior IR. Repair process of surgical defects filled with autogenous bone grafts in tibiae of diabetic rats. Journal of Applied Oral Science. 2008; 16(5):316-20. PMid:19089227. http://dx.doi.org/10.1590/S1678-77572008000500003

Galkowska H, Wojewodzka U, Olszewski WL. Chemokines, cytokines, and growth factors in keratinocytes and dermal endothelial cells in the margin of chronic diabetic foot ulcers. Wound Repair Regeneration. 2006; 14:55865. PMid:17014667. http://dx.doi.org/10.1111/j.17436109.2006.00155.x

Gundersen HJ, Bendtsen TF, Korbol L, Marcussen N, Moller A, Nielsen K, Nyengaard JR, Pakkenberg B, Sorensen FB, Vesterby A. Some new simple and efficient stereological methods and their use in pathological research and diagnosis. APMIS: acta pathologica, microbiologica, et immunologica. 1988; 96(5):379-94. PMid:3288247. http:// dx.doi.org/10.1111/j.1699-0463.1988.tb05320.x

Harinantenaina L, Tanaka M, Takaoka S, Mogami MOO, Uchida M, Asakawa Y. Momordica charantia constituents and antidiabetic screening of the isolated major compounds. Chemical and Pharmaceutical Bulletin. 2006; 54:1017-21. PMid:16819222. http://dx.doi.org/10.1248/cpb.54.1017

Honório-França AC, Marins CMF, Boldrini F, França EL. Evaluation of hypoglycemic activity and healing of extract from amongst bark of "Quina do Cerrado" (Strychnos pseudoquina ST. HILL). Acta Cirurgica Brasileira. 2008; 23(6):504-10. PMid:19030749. http:// dx.doi.org/10.1590/S0102-86502008000600007

Kim B, Eichler MJ, Reiser KM, Rubenchik AM, Silva LB. Collagen structure and non linear susceptibility: effects of heat, glycation, and enzymatic cleavage on second harmonic signal intensity. Lasers in Surgery and 
Medicine. 2000; 27:329-35. http://dx.doi.org/10.1002/10969101(2000)27:4<329::AID-LSM5>3.0.CO;2-C

Kozielski M, Buchwald T, Szybowicz M, Błaszczak Z, Piotrowski A, Ciesielczyk B. Determination of composition and structure of spongy bone tissue in human head of femur by Raman spectral mapping. Journal of Materials Science. 2011; 22:1653-61.

Lieber CA, Majumder SK, Ellis DL, Billheimer DD, Jansen A. In vivo non melanoma skin cancer diagnosis using raman microspectroscopy. Lasers in Surgery and Medicine. 2008; 40:461-7. PMid: 18727020 PMCid:PMC2782422. http://dx.doi.org/10.1002/1sm.20653

Martins NLP, Malafaia O, Ribas-Filho JM, Heibel M, Baldez RN,Vasconcelos PRL, Moreira H, Mazza M, Nassif PAN, Wallbach TZ. Análise comparativa da cicatrização da pele com o uso intraperitoneal de extrato aquoso de Orbignya phalerata (babaçu). Estudo controlado em ratos. Acta Cirurgica Brasileira. 2006; 21(Suppl.3):66-75. PMid:17293939. http:// dx.doi.org/10.1590/S0102-86502006000900010

Oliveira PK, Tosato MG, Alves RS, Martin AA, Fávero PP, Raniero L. Análise da composição bioquímica da pele por espectroscopia Raman. Revista Brasileira de Engenharia Biomédica. 2012; 28(3):278-87. http://dx.doi.org/10.4322/ rbeb.2012.032

Papanas N, Maltezos E. Polyherbal formulation as a therapeutic option to improve wound healing in the diabetic foot. Indian Journal of Medical Research. 2011; 134(2):146-7. PMid:21911965.
Piva JAAC, Abreu EMC, Silva VS, Nicolau RA. Effect of low-level laser therapy on the initial stages of tissue repair: basic principles. Anais Brasileiros de Dermatologia. 2011; 86(5):947-54. PMid:22147035. http:// dx.doi.org/10.1590/S0365-05962011000500013

Ponrasu T, Suguna L. Efficacy of Annonasquamosa on wound healing in streptozotocin-induced diabetic rats. International Wound Journal. 2012; 9(6):613-23. PMid:22233431. http:// dx.doi.org/10.1111/j.1742-481X.2011.00924.x

Silva HR, Silva CCM, Caland Neto LB, Lopes JAD, Citó AMGL, Chaves MH. Constituintes químicos das cascas do caule de Cenostigma macrophyllum: ocorrência de colesterol. Química Nova. 2007; 30(8):1877-81. http:// dx.doi.org/10.1590/S0100-40422007000800015

Sousa CMM, Silva HR, Vieira Júnior GM, Ayres MCC, Costa CLS, Araújo DS, Cavalcante LCD, Barros EDS, Araújo PBM, Brandão MS, Chaves MH. Fenóis totais e atividade antioxidante de cinco plantas medicinais. Química Nova. 2007; 30:351-7. http://dx.doi.org/10.1590/S010040422007000200021

Wang YF, Que HF. Effects of Chinese herbal medicine YiqiHuayu formula on substance $\mathrm{P}$ expression in skin ulcers of rats with diabetes mellitus. 2011; 9(12):1367-72.

Zhang Q, Chan KLA, Zhang G, Gillece T, Senak L, Moore DJ, Mendelsohn R, Flach CF. Characterization of Hydration in Collagen and Dermal Tissue. Biopolymers. 2011; 95(9):607-15. PMid:21394716. http:// dx.doi.org/10.1002/bip.21618

\title{
Authors
}

\section{Nayana Pinheiro Machado de Freitas Coelho*, Marcelino Martins}

Faculdade Diferencial Integral - FACID, Rua Miosótis, 303, ap. 2202, CEP 64049-536, Teresina, PI, Brasil.

\author{
Nayana Pinheiro Machado de Freitas Coelho, Charlytton Luís Sena da Costa,Antônio Luís Martins Maia Filho, Marcelino Martins
} Universidade Estadual do Piauí - UESPI, Teresina, PI, Brasil. 